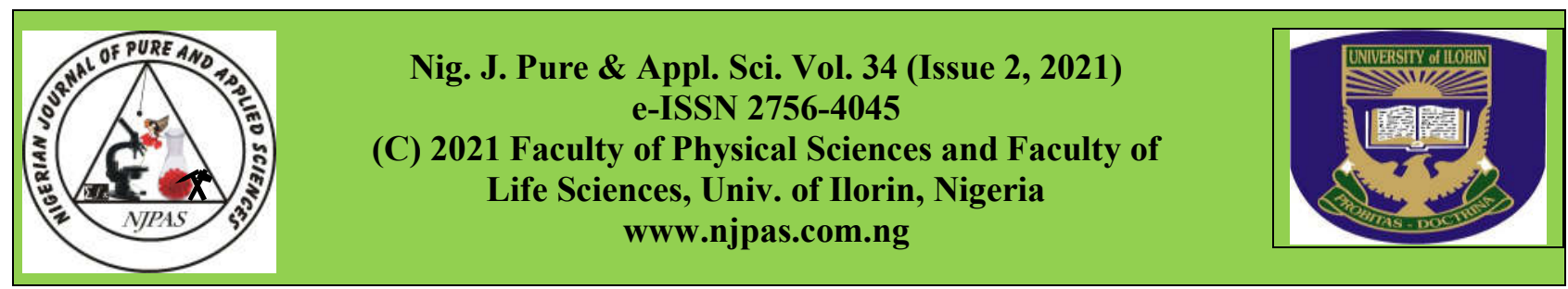

\title{
Quantitative Analysis and Antimicrobial Susceptibility of Enteric Bacteria Isolated from Surfaces of Canned Soft Drinks and Handlers from Selected Institutions in Zaria, Kaduna State
}

Page | 4040

*Obiefuna, O. I., Mbah, C. E. and Amlabu, W.E.

Department of Zoology, Faculty of Life Sciences, Ahmadu Bello University Zaria, Kaduna State, Nigeria

Date Received: 11-06-2021

Date Accepted: 28-09-2021

DOI: https://doi.org/10.48198/NJPAS/21.B04

\section{ABSTRACT}

The potentially major importance but currently unstudied trend of enteric bacterial contamination on surfaces of canned drinks forms the basis of the research. A study was carried out to determine the antimicrobial susceptibility of selected enteric bacteria on the surface of canned soft drinks and its handlers (palms of consumers) from selected tertiary institutions in Zaria. Two hundred and sixteen swabs were collected from the external surfaces of canned soft drinks and its handlers, thirty-six swabs each from cans and hand swabs were also collected from designated whole sellers known as Distributors. The samples were screened and analyzed using Spread Plate Method, Microgen GNA System for identification for enteric bacteria in three institutions in Zaria, Kaduna State. Kirby-Bauer disk diffusion method was employed for antimicrobial susceptibility test. The results showed that the total bacteria count of canned soft drinks and its handlers in the three institutions range from $1.0 \times 10^{4}$ to $3.0 \times 10^{7} \mathrm{cfu} / \mathrm{ml}$. Fourteen species of the Family Enterobacteriaceae were identified. The predominant species observed on canned soft drinks were Citrobacter freundii and Klebsiella ozaenae while that of its handlers were Citrobacter freundii and Escherichia coli. Perfloxacin (66.7\%) in ABU, perfloxacin (66.7\%) in FCE and ciprofloxacin (88.9\%) in POLY were highly sensitive against the isolates, while imipenem and ampicillin had (57.6\%) in ABU, ofloxacin (73.3\%) in FCE and Amoxicillin-Clavulanic (66.7\%) in POLY were found to be non-susceptible. The study showed that surfaces of canned soft drinks and its handlers in Zaria are significantly contaminated with enteric bacteria. Hence, incorporation of routine check of canned drinks in the health system is required. There is low antimicrobial activity by the antibiotic against the isolates, this poses serious health implications and requires further investigation.

Keywords: Enteric bacteria, contamination, antimicrobial, susceptibility.

\section{Introduction}

Soft drinks are sweetened, water-based beverages, usually with balancing acidity. Soft drinks are consumed worldwide and it represents a significant market within the food industry (Mooji, 2018) and is largely consumed by children and the working class daily, especially in the rush hours (Pettigrew et al., 2015). Its origin is dated back to two thousand years ago when Greeks and Romans recognized the medicinal value of mineral water and bathed it for relaxation

Corresponding Author: Obiefuna, O. I.,

Department of Zoology, Faculty of Life Sciences, Ahmadu Bello University Zaria, Kaduna State, NigeriaPhone: +2347031990073: Email: crystalpearl4life@gmail.com 
(Sordu et al., 2016). Soft drink constitutes a diverse group of products that can be classified based on their sugar and fruit juice content, flavouring, carbonation level, ingredients, and functionality (Pranita et al., 2015; Kregiel, 2015).

Page | 4041 There are many ways of producing soft drinks as producers find inventive ways of breathing new life into old-time brands by updating the products that are appealing to consumer (Lantos, 2015). According to Salako et al. (2016), non-alcoholic drinks are admittedly vital vehicles of a balanced diet and have also turned out to be a drink preferred in most social, health or religious gathering (Romo et al., 2015). These drinks are easily absorbed providing hydration, refreshment, and energy as well as replenishing the human body with all the key vitamins and minerals (Salako et al., 2016). Soft drinks are packed in bottles, laminated paper packs, pouches, cups and cans (Kregiel, 2015). These packaging materials is a means of storage and prevention from damage (Brockgreitens and Abbas, 2016).

Cans are one of the most accepted forms of packaging today due to its numerous advantages, such as it is one of the least expensive and most recyclable metal substances in the market. Therefore, many health concerns for this packaging method have been overlooked due to the financial and sustainability benefits (Stenberg et al., 2017). Consumers frequently drink straight from the package, and, in this case, the package enters into direct contact with the consumer's mouth. According to Pranita et al. (2015), cans and bottles can serve as sources of contamination, leading to large-scale disease outbreaks.

Infectious diseases caused by pathogenic enteric bacteria are the most common and widespread health risk diseases (Singer et al., 2017). These organisms can live on inanimate surfaces for an extended period (Russotto et al., 2015). It has also been observed that bacteria can grow in a low nutrient medium and exhibit resistance even to harsh conditions and antibiotics (Moretro and Langsrud, 2017). Food, hands, utensils and clothing are associated with domestic sanitation and poor hygiene. Also, the type of microflora on the hands, arms, nasal cavities, mouth or garments of vendors, reflects their sanitary state (Alum et al., 2016). Enteric diseases are common cause of illness and death in the developing world. They can cause disease when they gain access to the host, adhere to host tissue, penetrate host defenses and damage host tissue (Scallan et al., 2015). Bacillus species are one of the most virulent and destructive pathogens. Food-poisoning are attributed to Bacillus cereus since 1906 (Kigigha and Jonathan, 2012). The Gram-negative bacteria including Alcagenes, Pseudomonas, Escherichia coli, Serratia and Proteus, indicating probable faecal contamination causes severe diarrhoea (Kigigha and Jonathan, 2012).

There is paucity of reports on the health risk assessment that could arise from the consumptions of soft drinks directly from the orifice of canned soft drinks. This study aims to determine the bacterial load, isolate, identify, and evaluate the antimicrobial susceptibility of selected enteric bacteria on the surfaces of canned soft drinks and its handlers in the study area.

\section{Materials and Methods Study area}

This study was conducted in three tertiary institutions in Zaria which included; Ahmadu Bello University Main Campus $\left(11^{\circ} 02.268^{\prime} \mathrm{N}\right.$, $\left.007^{\circ} 40.397^{\prime} \mathrm{E}\right)$, Federal College of Education Kongo $\left(11^{\circ} 05.020^{\prime} \mathrm{N}, 007^{\circ} 43.791^{\prime} \mathrm{E}\right)$ and Nuhu Bamali Polytechnic $\left(11^{\circ} 02.140^{\prime} \mathrm{N}, 007^{\circ} 40.336^{\prime} \mathrm{E}\right)$. The sample size was determined using the formula described by Kogi (2019).

Thus, $N=\frac{Z^{2}(1-P)}{2 d^{2}}$

Where

$\mathrm{N}=$ Sample size

$\mathrm{Z}=1.96$ at $95 \%$ 
$\mathrm{P}=$ Prevalence $=78.9 \%$ (Kigigha and Jonathan, 2012)

$\mathrm{d}=$ Level of precision $(0.05)$

Page | 4042 Therefore, $N=\frac{Z^{2}(1-P)}{2 d^{2}}=\frac{1.96^{2}(1-0.789)}{2 \times 0.05^{2}}=162$

Bacteriological analysis was conducted at the Microbiology Laboratory, Department of Microbiology, Faculty of Life Sciences, Ahmadu Bello University Zaria, Kaduna State, Nigeria.

\section{Collection of Samples}

A total of 216 samples was collected which includes 108 swabs from cans of soft drinks obtained from kiosks stored in the refrigerators or in cooler box with ice blocks placed on them and 108 swabs of consumer's palms that bought the drink at the time of the study. From each of the tertiary institutions, 36 swabs of cans and 36 hand swabs were taken from designated whole sellers known as Distributors in the institutions were randomly selected. Each swab stick was moistened using sterile normal saline then the moistened swab stick was used to swab the surface of the canned soft drinks and the handler's hand that gave their approval by filling the consent form and immediately placed in sterile plastic bags and taken to the laboratory for analysis.

\section{Preparation of Culture Media and Total Bacteria Counting}

The media was prepared according to the manufacturer's specification. The swab sticks used to swab the cans and its handlers hand were cut aseptically into $9 \mathrm{ml}$ of sterile peptone water and was shaken vigorously for $15-20$ seconds. Afterwards, several dilutions were made up to dilution $10^{3}$ and $0.1 \mathrm{ml}$ was plat out of the dilution $10^{3}$. The diluent was inoculated in nutrient agar by spread method and incubated for 24 hours at $37^{\circ} \mathrm{C}$ (Barrow and Feltham, 2004). Discrete single colonies were counted as $\mathrm{cfu} / \mathrm{ml}$ (Cheesbrough, 2006).

\section{Sample Processing and Qualitative Detection of Bacteria}

The diluent, $0.1 \mathrm{ml}$ was transferred to selective and differential agar media (Eosin methylene blue agar and MacConkey agar respectively) and a sterile wire loop was used to struck the diluent by streaking in two directions at right angles over the surfaces of the agar media and incubated at $37^{\circ} \mathrm{C}$ for 24 hours (Murugalatha et al., 2012). Discrete single colonies were picked and inoculated onto nutrient agar slant bottle, isolation and cultivation of bacterial species of public health importance was carried out. Relevant staining and biochemical tests were carried out on the isolated organisms recovered from the samples (Cheesebrough, 2006).

\section{Antibiotics Susceptibility Test}

The modified Kirby-Bauer disc diffusion method was used to determine the antibiotic susceptibility of the isolates to the various antibiotics, according to Turnidge et al (2006). Discrete colonies of the isolates were emulsified in $5 \mathrm{ml}$ of sterile normal saline and the turbidity adjusted to $0.5 \mathrm{McFarland}$ standard (approximately a cell density of $1.5 \times 10^{8}$ $\mathrm{cfu} / \mathrm{ml})$. The standardized suspension was inoculated on Mueller Hinton agar and spread using a sterile swab to ensure even distribution and confluent growth. The sensitivity disc of the various selected antibiotics was aseptically placed using a sterile forceps on the dried inoculated agar surface. The plates were then incubated at $37^{\circ} \mathrm{C}$ for 18 hours. The plates were examined for the zones of inhibition, and were measured in micrometre and the result interpretation according to EUCAST (2013). The antibiotics used include: Ciprofloxacin $(5 \mu \mathrm{g}) \quad$ Trimethoprim-sulfamethoxazole $(30 \mu \mathrm{g})$, Amikacin $(30 \mu \mathrm{g})$, Gentamycin $(10 \mu \mathrm{g})$, Amoxycilin/clavulanic acid $(30 \mu \mathrm{g})$, Imipenem $(10 \mu \mathrm{g})$, chloramphenicol $(30 \mu \mathrm{g})$, Perfloxacin $(5 \mu \mathrm{g})$, Ofloxacin $(5 \mu \mathrm{g})$ and Ampicillin $(10 \mu \mathrm{g})$. EUCAST (2013). 


\section{Statistical Analysis}

The obtained data in this research were exposed to version 21.0 of SPSS statistical package. Descriptive statistics were employed to both Page | 4043 determine the level of contamination as well as the susceptibility profile of obtained isolates.

\section{Results}

The canned drink surfaces and the handlers showed the highest mean microbial load among the kiosk located in FCE Kongo (15.65 $\times$ $\left.10^{5} \mathrm{cfu} / \mathrm{ml}\right)$ and $\left(6.49 \times 10^{5} \mathrm{cfu} / \mathrm{ml}\right)$. While the least were among kiosks located in ABU Main Campus $\left(9.84 \times 10^{5} \mathrm{cfu} / \mathrm{ml}\right)$ and $(4.73 \times$ $\left.10^{5} \mathrm{cfu} / \mathrm{ml}\right)$. (Table 1).

Table 1: Microbial load of Cans and their Handlers in the three Institutions

\begin{tabular}{lll}
\hline \multirow{2}{*}{ Schools } & $\begin{array}{l}\text { CAN Colony } \\
\text { count }\left(\mathrm{cfu} / \mathrm{ml} \times 10^{5}\right)\end{array}$ & $\begin{array}{l}\text { HANDLER } \\
\text { Colony } \\
\text { count } \\
\text { x10 }\end{array}$ \\
\cline { 2 - 3 }$(\mathrm{cfu} / \mathrm{ml})$ \\
\hline ABU & Mean \pm SEM & SEM \\
FCE & $9.11 \pm 0.59^{\mathrm{a}}$ & $4.73 \pm 0.90$ \\
POLY & $4.38 \pm 0.98^{\mathrm{a}}$ & $6.49 \pm 1.45$ \\
F-value & 4.978 & $5.93 \pm 1.48$ \\
P-Value & 0.009 & 0.475 \\
\hline
\end{tabular}

$\mathrm{n}=216$. Values on the same column with different superscripts, a,b, are significantly different $(\mathrm{p}<0.05)$.

\section{Bacterial load on Cans and distributors hands in the selected Institutions}

Among the schools sampled, it was observed that swabs from the external surfaces of canned soft drinks had the highest isolation of enteric organisms. In contrast, samples obtained from distributors (samples in crates before removal of cover) were found to be devoid of contamination although hand swabs taken from a representative of the distributors' stores had bacterial growth (Figure 1).

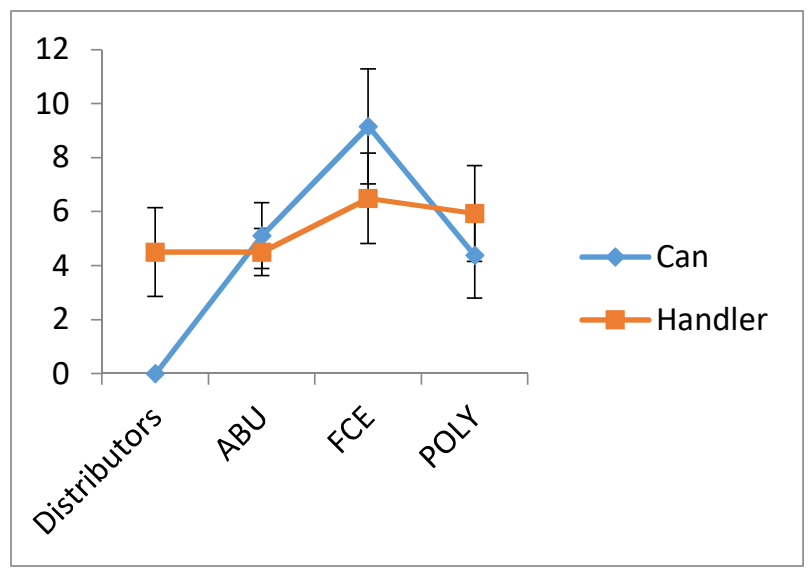

Figure 1: Cans and Handlers bacterial load of distributors of soft drinks and the selected Institutions.

\section{Isolation and Identification of Isolates}

Fourteen bacterial were identified belonging to the family Enterobacteriaceae and several genera subsumed under, Klebsiella 3, Serratia 2, and Proteus 2 while other genera occurred only once. The isolation was highest in Citrobacter freundii (26.30\%) and the least was (0.9\%) among Serratia marcescens, Proteus mirabilis, Klebsiella oxytoca and Proteus vulgaris (Figure 2).

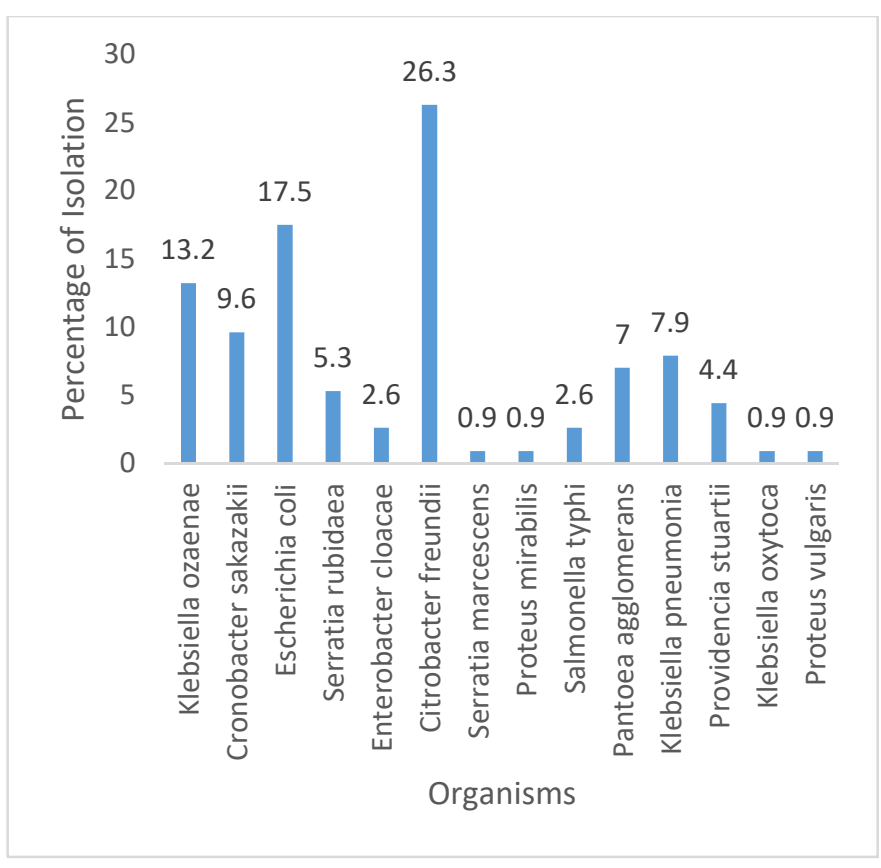

Figure 2: Isolated bacterial and percentages 
Distribution of Isolates by Sample Source and study locations

Serratia rubidaea, Citrobacter freundii and Salmonella typhi are the bacterial that are Page | 4044 statistically associated with surfaces of canned drinks $(\mathrm{P}<0.05)$ in the study sites. While Enterobacter cloacae, Pantoea agglomerans and Providencia stuartii are significantly associated with the soft drink handlers in this study $(\mathrm{P}<$ 0.05) (Table 2).
Antimicrobial Susceptibility of Enterobacteriaceae Isolates from surfaces of Cans drinks and Handlers

The antimicrobial susceptibility test of the antibiotics had low antimicrobial activities against the Enterobacteriaceae isolates in this study. Most isolates had low antimicrobial activity to imipenem and ofloxacin of $66.7 \%$, and $73.3 \%$ respectively. The antibiotics with the highest antimicrobial activity against the isolates are amikacin, and ciproploxacin 24.4 and $2.8 \%$ (Figure 3).

Table 2: Distribution of Isolates by Sample Source and School

\begin{tabular}{|c|c|c|c|c|c|c|c|c|c|c|}
\hline \multirow[t]{2}{*}{ Organisms } & \multicolumn{5}{|l|}{ Cans } & \multicolumn{5}{|l|}{ Handlers } \\
\hline & A.B.U & F.C.E & POLY & Chi square & P-value & A.B.U & F.C.E & POLY & Chi square & P-value \\
\hline Klebsiella ozcence & 3 & 6 & 3 & 1.528 & 0.466 & 1 & 2 & 0 & 2.009 & 0.366 \\
\hline $\begin{array}{l}\text { Cronobceter } \\
\text { sakazelä }\end{array}$ & 4 & 5 & 0 & 4.732 & 0.094 & 0 & 2 & 0 & 4.012 & 0.134 \\
\hline Escherichie coli & 5 & 3 & 1 & 2.704 & 0.259 & 1 & 6 & 4 & 3.514 & 0.174 \\
\hline Serratie nubidaea & 4 & 0 & 0 & 8.050 & 0.018 & 2 & 0 & 0 & 4.012 & 0.134 \\
\hline $\begin{array}{l}\text { Enterobacter } \\
\text { doacae }\end{array}$ & 0 & 0 & 0 & $\mathrm{NA}$ & NA & 3 & 0 & 0 & 6.028 & 0.049 \\
\hline Cirobacter frewtiï & 0 & 9 & 10 & 9.868 & 0.007 & 3 & 5 & 3 & 0.740 & 0.691 \\
\hline Serratic mercescens & 0 & 0 & 0 & $\mathrm{NA}$ & NA & 1 & 0 & 0 & 2.003 & 0.367 \\
\hline Protens mirabilis & 0 & 0 & 0 & $\mathrm{NA}$ & NA & 0 & 0 & 1 & 2.003 & 0.367 \\
\hline Salmonelle nphi & 0 & 3 & 0 & 6.028 & 0.049 & 0 & 0 & 0 & NA & NA \\
\hline $\begin{array}{l}\text { Pantoea } \\
\text { agglomerans }\end{array}$ & 0 & 1 & 4 & 5.240 & 0.073 & 0 & 3 & 0 & 6.028 & 0.049 \\
\hline $\begin{array}{l}\text { aglomerans } \\
\text { Klebsiella } \\
\text { pnewnoniace }\end{array}$ & 3 & 0 & 3 & 3.028 & 0.220 & 2 & 0 & 1 & 2.009 & 0.366 \\
\hline Providencia stuertï & 0 & 0 & 1 & 2.003 & 0.367 & 0 & 0 & 4 & 8.050 & 0.018 \\
\hline Klebsiella oxytoca & 0 & 0 & 0 & $\mathrm{NA}$ & NA & 1 & 0 & 0 & 2.003 & 0.367 \\
\hline Protous vulgeris & 0 & 0 & 0 & NA & NA & 0 & 0 & 1 & 2.003 & 0.367 \\
\hline TOTAL & $19(16.7 \%)$ & $27(23.7 \%)$ & $22(19.3 \%)$ & & & $14(12.3 \%)$ & $18(15.8 \%)$ & $14(12.3 \%)$ & & \\
\hline
\end{tabular}




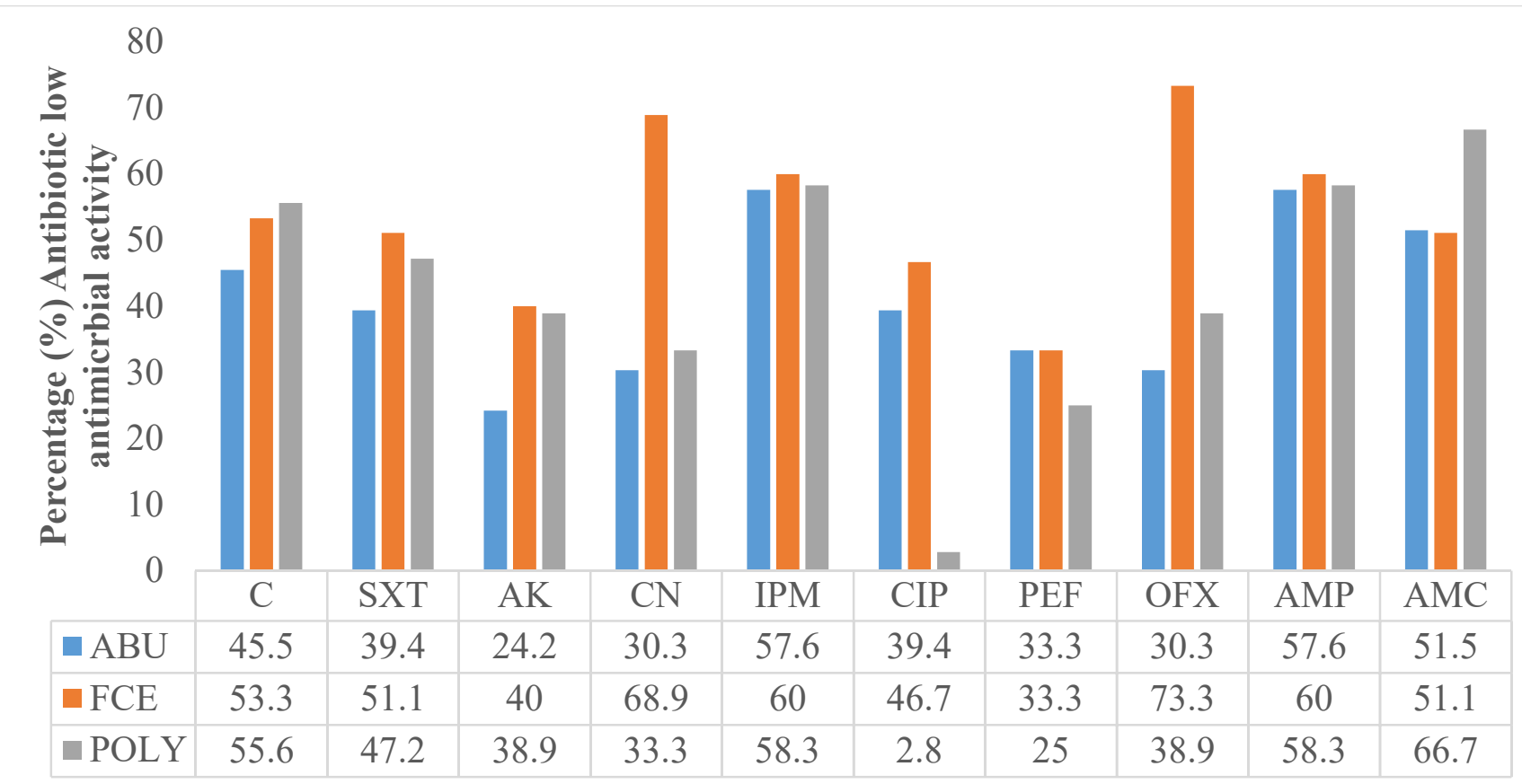

Figure 3. Antimicrobial Susceptibility of Enterobacteriaceae Isolates from Cans and Handlers

\section{Discussion}

Surfaces of canned drinks can be readily contaminated and might contribute to the risks of foodborne diseases if necessary hygienic measures are not observed or adhered to by the consumers (Alimi, 2016). In this study the total bacterial load of total viable count (TVC) revealed that the samples had counts ranged between $1.0 \times 10^{4} \mathrm{cfu} / \mathrm{ml}$ and $3.0 \times 10^{7} \mathrm{cfu} / \mathrm{ml}$ which is above the standard level of acceptable threshold of number of bacteria count of portable product for consumption $\left(<10^{4} \mathrm{cfu} / \mathrm{ml}\right.$ by National Agency for Food and Drug Administration and Control (NAFDAC).

It was observed that swabs from the external surfaces of canned soft drinks had the highest isolation of enteric organisms, while samples obtained from distributors (samples in trays before removal of the shrink film) had noncontaminated with any of the enteric bacteria. This may be attributed to the poor hygienic practices of the vendors as well as the surrounding conditions where these drinks where the drinks are sold in an unhygienic cooler with ice block which do not last long due to epileptic power supply this favours the survival and proliferation of the enteric bacterial isolated. These findings agree with Abraham et al. (2018) work on qualitative detection and isolation of bacteria from surfaces of canned drinks in Ugbor, Benin City, who observed 100\% contamination of bacteria for analyzed samples from kiosks while all samples obtained from distributors were found to be non-contaminated. This is probably because the contaminations recorded in the analyzed samples were not from the manufacturers of canned soft drinks but rather from the vendors. The surface contamination observed is a clear indication of poor hygienic practices of vendors which is commonly associated with bacterial growth. Canned soft drinks in the study area are stored in ice slurry, which are potentially translocation of 
bacteria between contaminated surfaces and the vendors (Dawson et al., 2018). Abraham et al. (2018) also noted that surfaces of canned drinks were readily contaminated, irrespective of whether they are kept in the refrigerator or not.

A total of fourteen microorganisms belonging to ten different genera was isolated from the external surfaces of canned soft drinks and handlers. The genera are Klebsiella, Cronobacter, Escherichia, Serratia, Enterobacter, Citrobacter, Proteus, Salmonella, Pantoea and Providencia. According to Abdulkadir and Mugadi (2012), the presence of most of these species can be attributed to the fact that they are commonly found in the environment and have been reported to be common contaminants. Some of these identified pathogens can survive on hands, external surfaces of packaging materials and other objects (Kilic et al., 2009) for several days and weeks after contact (Dantas et al., 2006). However, their presences in some of the commercial samples are of public health concern since some of the organisms are associated with some form of disease conditions such as gastroenteritis (Ogodo et al., 2008). The predominant species observed on canned soft drinks were Citrobacter freundii, Klebsiella ozaenae, Escherichia coli and Cronobacter sakazakii while that of its handlers were Citrobacter freundii and Escherichia coli. A study by Abraham et al. (2018) identified some enteric bacterial such as Staphylococcus aureus, Pseudomonas aeruginosa, Enterococcus species and Escherichia coli. The bacteria isolated in his work were fewer compared to the present study that recorded enteric bacteria on the surfaces of the canned soft drink examined in the study areas. Kusumaningrum et al. (2002) revealed that some bacteria, such as E. coli, Staphylococcus aureus and Pseudomonas aeruginosa may either directly or indirectly contaminate surfaces through aerosolized droplets. The isolation of these bacteria shows that canned surfaces and hands could act as a medium for the spread of both pathogenic and opportunistic microbes.

The antimicrobial susceptibility test revealed that most of the antibiotics had low antimicrobial activities against the Enterobacteriaceae isolates across the schools. In this study, Imipenem and ampicillin had the highest antimicrobial activity (58.6\% each) whereas ciprofloxacin $(29.6 \%)$ was the least active antibiotic against the isolated bacteria from the samples analyzed. This finding also concurs with the study of Igwe et al. (2016) in Zaria, who reported amoxicillin and ofloxacin to have low antimicrobial activities and amikacin was found to have high antimicrobial activity against E. coli although differed from ciprofloxacin which had low antimicrobial activity as against the high antimicrobial activity obtained in this study. Another report by Olayinka et al. (2009) in Zaria also reported ofloxacin to have low antimicrobial activity and ciprofloxacin and amikacin to have high antimicrobial activities. This varying ranges is notable to the fact that Ella et al. (2008) observed that antimicrobial susceptibility pattern differs in different studies as well as at different times in the same region because of emergence of resistant strains as a result of abuse of antibiotics.

In this study the total number of antibiotics to which the organisms were exposed showed a minimum of $96.9 \%$ isolates in MAR index $\geq 0.2$. The MAR indices obtained is a possible indication that high proportion of the bacteria isolates shave are been exposed to several antibiotics as also reported by Adeshina et al. (2012).

\section{Conclusion}

A total of $48.1 \%$ of the surfaces of canned soft drinks investigated are contaminated with enteric bacterial. Citrobacter freundii (16.7\%) and Klebsiella ozaenae (10.5\%) have the highest frequency in canned soft drinks while for handlers Citrobacter freundii and Escherichia 
coli have similar frequency of $9.6 \%$. Antibiotics such as ciprofloxacin, pefloxacin, amikacin are sensitive against the isolates while ofloxacin, amoxicillin, imipenen, ampicillin have low antimicrobial activities to the isolates. This poses Page | 4047 serious health implications, hence, incorporation of routine check of canned drinks in the health system is required.

\section{Acknowledgement}

We are grateful to Mr and Mrs C.D. Obiefuna for provision of funds for the study, Dr E.E. Ella for excellent technical assistance. We would like to acknowledge the help of Laboratory staff of Department of Microbiology, Ahmadu Bello University who assisted in the laboratory work.

\section{Competing Interest}

No conflict of Interest exists.

\section{References}

Abdulkadir, M. and Mugadi, A. G. (2012). Bacteriological examination of fura da nono (fermented milk; cereals mix) sold in some selected areas of Birnin Kebbi Metropolis. ARPN Journal of Science and Technology, 2, 333-340.

Abraham, O. G., Idowu, B. O. O., Barbara, A. U., Veadams, I. E. and Alexander, E. O. (2018). Qualitative Detection and Isolation of Bacteria from Surfaces of Canned Drinks Sold in Ugbor, Benin City. Annals of Science and Technology, 3(2), 20-25.

Adeshina, G. O., Jibo, S. D. and Agu, V. E. (2012). Antibacterial Susceptibility pattern of pathogenic Bacteria Isolates from Vegetable Salad Sold in Restaurants in Zaria, Nigeria. Journal of Microbiology Research, 2(2), 5-11.

Alimi, B.A. (2016). Risk factors in street food practices in developing countries. Food Sci. Hum. Wellnessm, 5,141-148.
Alum, E. A., Urom, S. M. and Ben, C. M. (2016). Microbiological Contamination of Food: The Mechanisms, Impacts and Prevention. International Journal of Scientific and Technology, 5(3), 65-78.

Barrow G. I. and Feltham, R. K. A. (2003). Cowan and Steel's manual for the identification of medical bacteria, Cambridge University Press, The Edinburgh Building, Cambridge CB2 2RU, UK. Pp $21-42$.

Brockgreitens, J. and Abbas, A. (2016). Responsive Food Packaging: Recent Progress and Technological Prospects. Comprehensive Reviews in Food Science and Food Safety, 15, 1-13.

Cheesbrough, M. (2006) District Laboratory Practice in Tropical Countries (Second Edition). Cambridge University Press. New York, United Kingdom. Pp 62- 72

Dantas, S. T., Silva, N. and Dantas, F. B. H. (2006). External Microbiological Contamination of Beverage Packaging. Brazilian Journal of Food Technology, 93, 193-199.

Dawson, P., Aljeddawi, W., Buyukyavuz, A., Han, I. and Martinez-Dawson, R. (2018). Bacteria on Can Lids. Journal of Food: Microbiology, Safety and Hygiene, 3, 140 147.

Ella, E. E., Ahmad, A. A., Ogala, W. N., Umoh, V. J., and Aliyu-Zubair, R. (2008). Bacteriology and sensitivity profile bacterial agents responsible for neonatal septicaemia in a tertiary hospital of Kaduna metropolis. Journal of Pure and Applied Microbiology, 2(1), 103-108.

European Committee on Antimicrobial Susceptibility Testing. (2013). EUCAST guidelines for detection of resistance 
mechanisms and specific resistances of clinical and/or epidemiological importance. EUCAST, Basel, Switzerland: http://www.eucast.org/clinical_breakpoint $s$.

Page | 4048
Igwe, J. C., Onaolapo, J. A., Ehimidu, J. O., Bolaji, R. O., Tytler, A. B., Ojiego, B. O. and Salihu, M. S. (2016). Antibiotic susceptibility profile of E. coli serotype O157: H7 in ABUTH, Zaria, Nigeria. Int $J$ Trop Dis Health, 11(1), 1-8.

Kigigha, L. T and Jonathan, G. (2012). Microbiological assessment of opened soft drink bottles for pathogenic bacteria associated with drinking directly from the orifice. Continental Journal of Microbiology, 6 (1), 26 - 32.

Kilic, L. H., Ozaslan, M, Karagoz, I. D., Zer, Y. and Davutoglu, V. (2009). The microbial colonization of mobile phone used by healthcare staff. Pakistan Journal of Biological Sciences. 121, 882-884.

Kregiel, D. (2015). Health Safety of Soft Drinks: Contents, Containers, and Microorganisms. BioMed Research International, 2015: 1-15. Retrieved from http://dx.doi.org/10.1155/2015/128697

Kusumaningrum, H. D., Riboldi, G., Hazeleger, W. C. and Beumer, R. R. (2002). Survival of food borne pathogens on stainless steel surfaces and cross-contamination to foods. International Journal of Food Microbiology, 85, 227-236.

Lantos, G. P. (2015). Consumer Behavior in Action: real-life applications for marketing managers. New York: Routledge. pp 1533. ISBN 13: 9780765620903.

Mooji, D. M. (2018). Global Marketing and Advertising: Understanding cultural paradoxes (5th ed.). SAGE publication Ltd, London. pp 1-372.

Moretro, T. and Langsrud, S. (2017). Residential Bacteria on Surfaces in the Food Industry and Their Implications for Food Safety and Quality. Comprehensive Reviews in Food Science and Food Safety, 16: 1022-1041.

Murugalatha, N., Growther, L., Hena, J. V., Shenpagam, N. H., Anitha, R., Devi, D. K. and Rajalakshmi, G. (2012). Microbiological techniques. MJP Publisher. Chennai New Delhi Tirunelveli and India. Pp. 1- 401

Ogodo, A. C., Agwaranze, D. I., Onudibia, M. E. and AwacheI, A. L. (2008). Study on the bacteriological quality of fura sold in Wukari, North-East Nigeria. Journal of Food Microbiology, 2(1), 24-29.

Pettigrew, S., Jongenelis, M., Chapman, K., and Miller, C. (2015). Factors influencing the frequency of children's consumption of soft drinks. Elsevier, 91: 393-398. Retrieved from https://doi.org/10.1016/j.appet.2015.04.08 0

Pranita, A., Gulhane, A. V. and Gomashe, D. N. (2015). Microbiological stability of soft drink: An approach for annihilation of spoilage bacteria. International Journal of Technical Research and Applications, 3(4), 299-303.

Romo, K. L., Dinsmore, D. R., Connolly, L. T., and Davis, C. N. (2015). An Examination of How Professionals Who Abstain from Alcohol Communicatively Negotiate Their Non-drinking Identity. Journal of Applied Communication Research, 43(1): 91-111.

Russotto, V., Cortegiani, A., Raineri, M., and Giarratano, A. (2015). Bacterial 
contamination of inanimate surfaces and equipment in the intensive care unit. Journal of Intensive Care, 3, 5462.

Salako, S. G., Adekoyeni, O. O., Adegbite, A. Page | 4049 A., and Hammed, T. B. (2016). Determination of Metals Content of Alcohol and Non-alcoholic Canned Drinks Consumed at Idiroko Border Town Ogun State Nigeria. British Journal of Applied Science and Technology, 12(6), 1-8.

Scallan, E., Hoekstra, R. M., Mahon, B. E., and Jones, T. F. (2015). An Assessment of The Human health impact of seven leading foodborne pathogens in the United States using disability adjusted life years. Epidemiology and Infection, 143(13), 2795-2804.

Singer, M., Bulled, N., Ostrach, B., and Mendenhall, E. (2017). Syndemics and the biosocial conception of health. The Lancet, 389(10072), 941-950.

Sordu, O., Onose, G., Blendea, D. and Surdu, T. V. (2016). Evergreen Balneology - The Romanian Paradigm: Inception and way ahead. La Presse Thermale et Climatique, Paris. 153, 189-197.
Stenberg, k., Hanssen, O., Edejer, T. T., Bertram, M., Brindley, C., Meshreky, A., Soucat, A. (2017). Financing transformative health systems towards achievement of the health Sustainable Development Goals: a model for projected resource needs in 67 lowincome and middle-income countries. Lancet Global Health, 5(9), 875-887.

Turnidge, J., Kahlmeter, G., and Kronvall, G. (2006). Statistical characterisation of bacterial wild-type MIC value distributions and the determination of epidemiological cut-off values. Clinical Microbiologic. Infection 12, 418-425.

Olayinka, A. T., Olayinka, B. O. and Onile, B. A. (2009). Antibiotic susceptibility and plasmid pattern of Pseudomonas aeruginosa from the surgical unit of a university teaching hospital in north central Nigeria. International Journal of Medicine and Medical Sciences, 1(3), 079083. 